\title{
Geologia e Geoquímica do Batólito Rapakivi Rio Branco, SW do Craton Amazônico - MT
}

\author{
Larissa Marques Barbosa de Araújo-Ruiz' (Imbar@rc.unesp.br), Antonio Misson Godoy², \\ Amarildo Salina Ruiz ${ }^{3}$, Maria Zélia Aguiar de Sousa ${ }^{4}$, Luiz Fernando de Mello Montano ${ }^{5}$ \\ 'Pós-Graduação em Geologia - Instituto de Geociências e Ciências Exatas - UNESP \\ Av. 24-A 1515, CEP 13506-900, Rio Claro, SP, BRA \\ ${ }^{2}$ Departamento de Petrologia e Metalogenia - IGCE - UNESP, São Paulo, SP, BRA \\ ${ }^{3}$ Departamento de Geologia Geral - ICET - UFMT, Cuiabá, MT, BRA \\ ${ }^{4}$ Departamento de Petrologia e Mineralogia - ICET - UFMT, Cuiabá, MT, BRA \\ ${ }^{5}$ Graduação em Geologia - IGCE - UNESP, São Paulo, SP, BRA \\ Recebido em 02 de março de 2006; aceito em 09 de março de 2007
}

Palavras-chave: Craton Amazônico, Batólito Rio Branco, Rapakivi, Anorogênico, Geoquímica.

\section{RESUMO}

O Batólito Rapakivi Rio Branco está inserido no Domínio Tectônico Cachoeirinha, parte da Província Geocronológica Rio Negro-Juruena, localizado na porção sudoeste do Craton Amazônico em Mato Grosso. Com base no mapeamento geológico sistemático na escala 1:100.000 e nos estudos petrográficos e geoquímicos dos litotipos que constituem o conjunto plutônico, foi possível redefinir a área de ocorrência desta unidade, sua constituição petrográfica e faciológica e caracterizar a litogeoquímica do magmatismo granítico. O batólito é constituído por duas suítes plutônicas principais, a primeira, formada pela suíte básica constituída por litotipos meso- a melanocráticos, cor cinza a negra, equigranulares finos, podendo exibir variedades porfiríticas com matriz fina, estrutura maciça, de distribuição descontínua e localizada nas bordas da intrusão e a segunda, pela suíte ácida/intermediária, constituída por granitos porfiríticos, granofíricos (com textura rapakivi), isotrópicos, de cor vermelha, com a presença de fenocristais de feldspato potássico, de até $4 \mathrm{~cm}$, envoltos em matriz fina a média. A suíte ácida é composta por três fácies petrográficas: 1. monzogranitos equi-inequigranulares a pegmatóides; 2. leuco-monzogranito vermelho rapakivi e 3. monzogranitos a quartzo-monzonitos vermelhos escuros rapakivi. As rochas apresentam valores de $\mathrm{SiO}_{2}$ entre $67 \%$ a 73\%, são peraluminosas a metaluminosas e definem um magmatismo da série cálcio-alcalina alto potássio a shoshonítica, em ambiente entre os tipos I e A de caráter pós-orogênico a anorogênico, gerados em ambiente intra-placa. Estes processos magmáticos encontram-se relacionados ao final do evento colisional, alcançando ambientes mais estáveis de consolidação e estabilização tectônica do SW do Craton Amazônico.

Keywords: Amazonian Craton, Rio Branco Batolith, Rapakivi, Anorogenic, Geochemistry.

\section{ABSTRACT}

The Rio Branco Rapakivi Batholith belongs to the Cachoeirinha Tectonic Domain, part of the Rio Negro-Juruena Geochronological Province located on the southwestern portion of the Amazonian Craton in Mato Grosso, Central Brasil. A systematic geological mapping on a 1:100.000 scale, coupled with petrographic and geochemical studies allowed to redefine this batholithic unit, to recognize faciological variations and to characterize the geochemical features of this rapakivi magmatism. The batholith is constituted by two major plutonic suites, the first forming a basic suite of fine-grained, equigranular, mesoto melanocratic gray to black lithotypes, with usually discontinuous porphyritic varieties located near the margins of the intrusion. The second one is characterized by acid to intermediate rocks constituted by porphyritic granites, in part granophyric, with rapakivi textures. They have K-feldspar phenocrysts of up to $4 \mathrm{~cm}$. Three distinct petrographic facies are recognized in this suite: 1. equigranular to pegmatitic monzogranites; 2. red rapakivi leuco-monzogranites; 3 . dark red rapakivi monzogranites to quartz-monzonites. Rocks present $\mathrm{SiO}_{2}$ contents from $67 \%$ to $73 \%$, show peraluminous to metaluminous compositions and define a high-K calc-alkaline to shoshonitic magmatism in an I- and A-type, post-orogenic to anorogenic intraplate environment. The magmatic processes are associated with the end of the collisional event that consolidated and stabilized the SW part of the Amazonian Craton. 


\section{INTRODUÇÃO}

O Batólito Rapakivi Rio Branco encontra-se inserido em rochas do Grupo Aguapeí do Domínio Cachoeirinha (Ruiz, 2005), formando um conjunto de corpos de idade mesoproterozóica pertencente à Província Geocronológica Rio Negro-Juruena (1,7 - 1,55 Ga) e é constituído pelas principais ocorrências de intrusões (ácida/básica) pós-cinemáticas do SW do Craton Amazônico, não afetadas pela Orogenia Sunsás (1,0 a 0,9 Ga) (Saes, 1999; Geraldes et al., 2004; Ruiz, 2005). Tal peculiaridade faz com que esta unidade seja uma importante fonte de dados sobre evolução crustal das orogenias San Ignácio-Rondoniana (1,5 a 1,3 Ga) e Sunsás (1,0 a 0,9 Ga).

O Batólito Rio Branco é descrito na literatura como sendo uma intrusão bimodal com aproximadamente $2.000 \mathrm{~km}^{2}$. As rochas que constituem a suíte intrusiva foram estudadas inicialmente por Oliva et al. (1979), sendo denominadas de Complexo Serra de Rio Branco. Barros et al. (1982) utilizam o termo Grupo Rio Branco e definem esta unidade como uma seqüência plutônica-vulcânica bimodal, constituída por rochas básicas (diabásios e gabros) e ácidas (riolitos, granito pórfiros, andesitos e dacitos) que ocorrem na região da serra homônima.

Leite et al. (1985) aplicam o termo Suíte Intrusiva Rio Branco, para englobar as rochas hipoabissais máficas e félsicas da Serra de Rio Branco, dividindo-a em duas unidades ígneas: a basal, unidade meso-melanocrática, composta por olivina-gabros, gabros e quartzo-dioritos e de topo, unidade leucocrática, formada por quartzo-monzonitos e sienitos, sugerindo que a intrusão seria de um complexo ígneo estratiforme diferenciado.

Geraldes (2000) e Geraldes et al. (2001, 2004) utilizam o termo Complexo Rio Branco e apresentam idades $\mathrm{U} / \mathrm{Pb}$ $1423 \pm 02$ Ma para os granófiros e $1469 \pm 31$ Ma para os gabros da Suíte Rio Branco e são interpretadas como idades de cristalização do plutonismo anorogênico, reforçando a dualidade deste magmatismo. As idades $\mathrm{T}_{\mathrm{Dm}}$ foram interpretadas como idades de extração mantélica e indicam que o protólito das rochas básicas foi formado entre 1,86 - 1,82 Ga e das félsicas entre 1,80 - 1,73 Ga.

Araújo-Ruiz et al. (2004) definem este magmatismo como Batólito Rapakivi Rio Branco caracterizado pelas suítes intrusivas Rio Branco de composição predominantemente ácida e a básica, de ocorrência restrita e localizada, mas não apresentando a mesma configuração areal inicial de Barros et al. (1982) e adotada por Leite et al. (1985), Geraldes (2000) e Geraldes et al. (2001, 2004). Quanto ao posicionamento estratigráfico, Leite et al. (1985), Geraldes (2000) e Geraldes et al. (2001, 2004), situam as rochas do batólito como embasamento do Grupo Aguapeí, enquanto os autores deste trabalho reforçam a posição inicial de
Barros et al. (1982), de um evento magmático intrusivo nas unidades do Grupo Aguapeí.

Em razão da importância desta unidade geológica na compreensão do magmatismo anorogênico do SW do Craton Amazônico e da evolução geológica do Mesoproterozóico, o presente trabalho tem o objetivo de apresentar os resultados da cartografia geológica na escala de 1:100.000 do Batólito Rio Branco e, com base nos dados petrográficos e geoquímicos, avaliar os processos petrogenéticos responsáveis pela geração da Suíte Intrusiva Ácida Rio Branco.

A área de estudo abrange parcialmente quatro folhas topográficas (Rio Branco, Camarcam, Nova Fernandópolis e Rio Sepotuba) na escala de 1:100.000, tendo como referência central a cidade de Rio Branco. O Batólito Rapakivi Rio Branco, agora redefinido na sua área geográfica, abrange cerca de $1.500 \mathrm{~km}^{2}$, constituindo um planalto entre os fortes da serra e em toda sua extensão compondo um relevo acidentado, na forma de colinas do tipo meia laranja, onde afloram suas rochas sob a forma de blocos e matacões.

\section{GEOLOGIA REGIONAL}

A evolução Proterozóica do Craton Amazônico, segundo Tassinari e Macambira (1999), é caracterizada pela acreção de cinturões móveis que se anexaram ao núcleo arqueano do protocraton Amazônico, possibilitando a identificação do Cinturão Maroni-Itacaiúnas (2,2 a 2,0 Ga), Cinturão Venturi-Tapajós (2,1 e 1,9 Ga), Província Rio Negro-Juruena (1,7 e 1,55 Ga), Província Rondoniana (1,5 e 1,3 Ga) e o Cinturão Sunsás/Aguapeí (1,0 e 0,9 Ga).

A proposta de compartimentação em Domínios Tectônicos apresentada por Ruiz (2005) e utilizada neste trabalho, subdivide a porção sudoeste do Craton Amazônico em cinco domínios tectônicos distintos denominados de Domínio Cachoeirinha, Jauru, Rio Alegre, Santa Bárbara e Paraguai (Figura 1). Dentro deste contexto, o Batólito Rapakivi Rio Branco está inserido no Domínio Cachoeirinha e o estudo do magmatismo desta região possibilita uma melhor visão dos processos magmáticos e tectônicos atuantes na geração do evento ígneo pós-cinemático de idades $\mathrm{U} / \mathrm{Pb}$ de 1,46 a $1,42 \mathrm{Ga}$.

O Domínio Tectônico Cachoeirinha proposto por Ruiz (2005) corresponde ao setor oriental dos terrenos précambrianos do sudoeste do Craton Amazônico em Mato Grosso, constituído pelas seguintes unidades litoestratigráficas, em ordem cronológica decrescente: Complexos Metavulcano-sedimentares Cabaçal e Quatro Meninas, Suíte Intrusiva Máfica-ultramáfica, Unidades Ortognáissicas, Tonalito Cabaçal, Suíte Intrusiva Santa Cruz, Suíte Intrusiva Alvorada, Grupo Aguapeí, Batólito Rio Branco e Suíte Intrusiva Salto do Céu. 


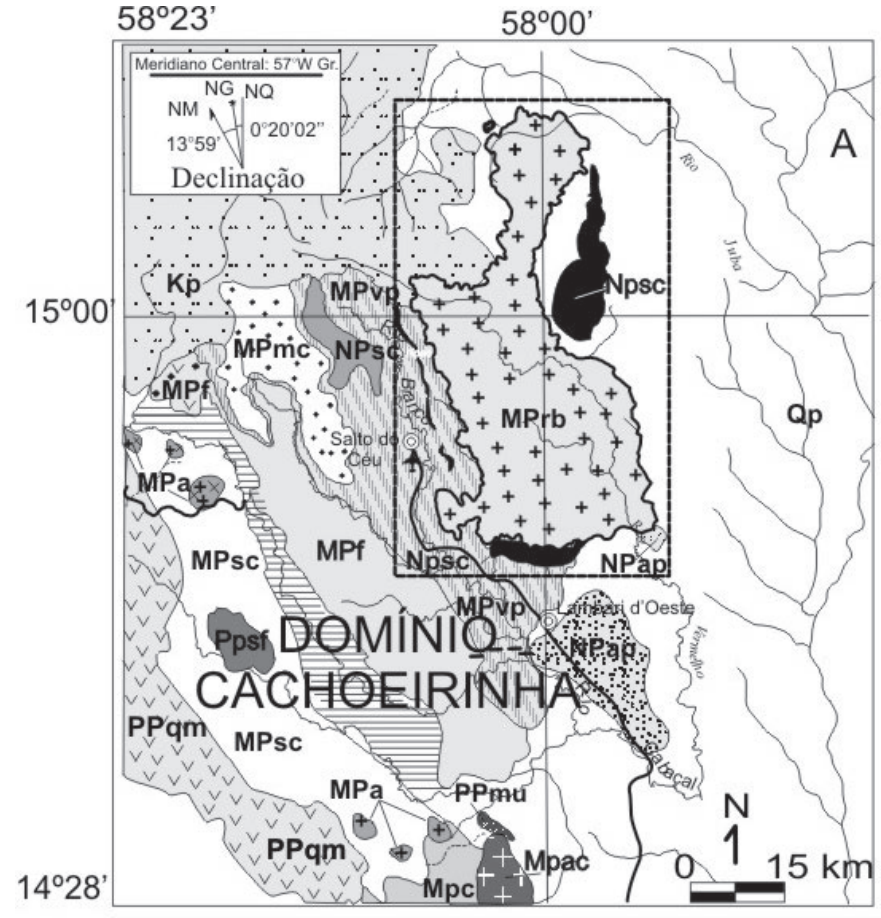

\begin{tabular}{l|l}
\hline Qp & Qp - Formação Pantanal \\
Kp. Kp - Grupo Parecis
\end{tabular}

\section{Domínio Cachoeirinha}

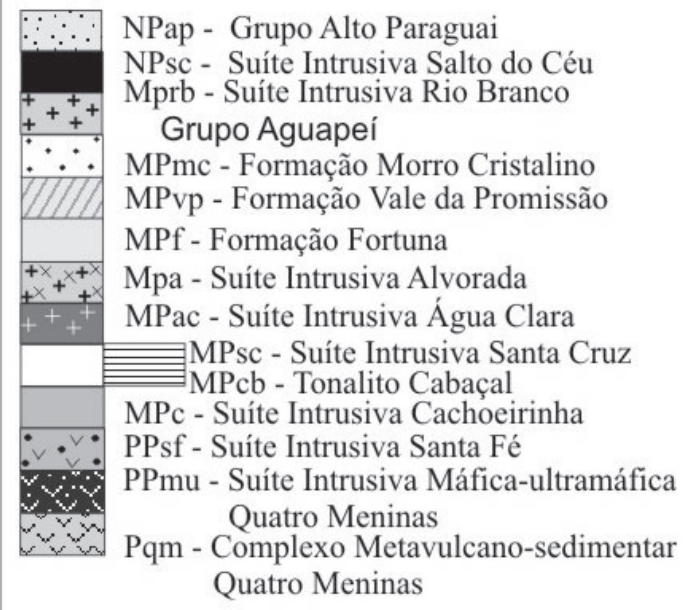

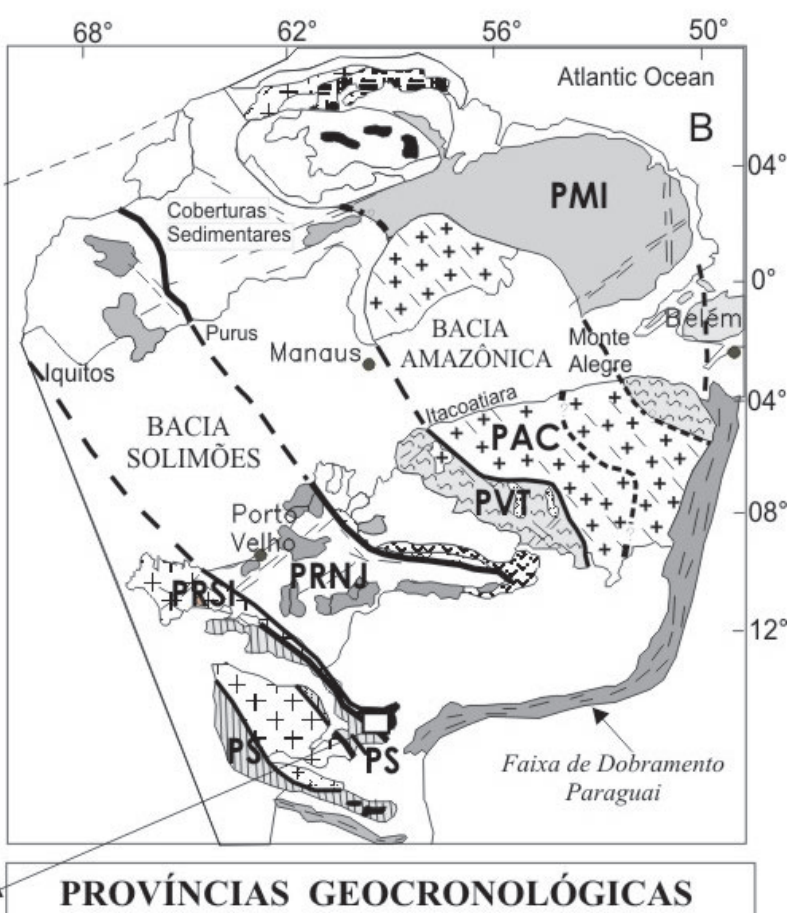

PAC-Amazônia Central: >2,3 Ga

PMI-Maroni-Itacaiúnas: 2,2 - 1,95 Ga

PVT-Ventuarí-Tapajós:1,95 - 1,8 Ga

PRNJ-Rio Negro-Juruena:1,8 - 1,55 Ga

PRSI-Rondoniana-San Ignácio: 1,5 - 1,15 Ga

PS-Sunsás: 1,1 - 0,9 Ga

Figura 1. A. Mapa geológico regional de Ruiz (2005), apresentando o Domínio Cachoeirinha com destaque para o Batólito Rapakivi Rio Branco. B. Situação da área dentro das províncias geocronológicas de Tassinari e Macambira (1999). 
Com base em recentes trabalhos de mapeamento geológico, Araújo-Ruiz et al. (2005a, 2005b) redefinem a área de ocorrência e a constituição litológica do Batólito Rapakivi Rio Branco. As relações de campo mostraram evidências de que as conhecidas associações gabróicas, não ocorrem somente na forma localizada e restrita de diques isolados e/ou concomitantemente formados com os granitos, mas também, constituem uma unidade independente na forma de extensas soleiras paralelas (formadas por diferentes níveis de microgabros e diabásios), que se alojam nas porções superiores da Formação Vale da Promissão.

A partir desta caracterização foi possível definir as rochas máficas da região de Salto do Céu e Rio Branco em duas unidades distintas:

1. as rochas básicas plutônicas (gabros a quartzo-gabros e dioritos a quartzo-dioritos) designadas de Suíte Intrusiva Básica Rio Branco, pertencentes à borda do Batólito Intrusivo Rio Branco;

2. os litotipos hipoabissais, diabásios e microgabros de idade toniana ( $\pm 950 \mathrm{Ma})$, constituindo dique e sills alojados nos estratos do Grupo Aguapeí e agrupados sob a designação Suíte Intrusiva Básica Salto do Céu.

Dados geocronológicos K-Ar (Barros et al., 1982) mostram valores próximos de 900 Ma para as rochas da Suíte Intrusiva Básica Salto do Céu, enquanto que as rochas da Suíte Intrusiva Básica Rio Branco apresentam idade U/Pb de 1,4 Ga (Geraldes, 2000).

A constatação por Ruiz (2005), da ocorrência de xenólitos de metargilitos da Formação Vale da Promissão em rochas do batólito e indícios de metamorfismo de contato de discreta expressão em metapelitos da mesma formação, indicam que as rochas metassedimentares do Grupo Aguapeí são mais antigas que as rochas do Batólito Rapakivi Rio Branco.

Datação pelo método SHRIMP U-Pb em xenotima diagenética e zircão detrítica da Formação Fortuna do Grupo Aguapeí fixa a idade de sua deposição entre $1167 \pm 27$ Ma e $1149 \pm 7$ Ma (Santos et al., 2005). Esse valor não discorda com o contexto geológico caracterizado pelo mapeamento, que indica a natureza intrusiva do Batólito Rio Branco em rochas sedimentares do Grupo Aguapeí. Os índices negativos de $\varepsilon_{\mathrm{Nd}(\mathrm{t})}$ e os valores elevados da razão inicial $\mathrm{Sr}^{87} / \mathrm{Sr}^{86}$ apresentados para o granito rapakivi, indicam a participação de fontes crustais na geração do magma parental.

Quanto ao caráter genético, há duas propostas para a bimodalidade do magmatismo Rio Branco. Leite et al. (1985) preconizam um modelo de evolução pela diferenciação de um magma basáltico toleítico em um lopolito, resultando em um complexo estratiforme diferenciado. Geraldes et al.
(2001, 2004) com base nos dados geoquímicos e geocronológicos, reavaliam o magmatismo bimodal da suíte, interpretando-o como uma interação de magmas máficos e félsicos através de processos de commingling $e$ mixing, descartando o modelo estratiforme por diferenciação in situ.

A evolução do Batólito Rio Branco ocorre após o episódio Orogênico Cachoeirinha (Ruiz, 2005) cerca de 1400 Ma, associado a um extenso período marcado pela estabilidade tectônica e/ou processos tafrogênicos que conduziram à formação da bacia intracratônica Aguapeí. Do encerramento deste episódio orogênico ao início do tectonismo reflexo da Orogenia Sunsás, ca. 1100 Ma (soleiras máficas), há um hiato de marcos orogênicos que corresponde ao Período Ectasiano e parte do Esteniano (1400 - $1100 \mathrm{Ma})$, denunciando a longa estabilidade tectônica vivenciada neste domínio.

A Bacia Sedimentar Aguapeí, segundo Saes (1999), teria evoluído em um regime tectônico extensional, responsável pela formação de estruturas do tipo riftes continentais, meridianamente orientados (Aulacógeno Aguapeí) e que controlaram a natureza da sedimentação siliciclástica. Diversos autores (Souza e Hildred, 1980; Barros et al., 1982; Saes et al., 1996; Saes, 1999) ao descreverem os registros deposicionais do Grupo Aguapeí, assinalam o caráter transgressivo-regressivo no preenchimento da bacia. O Grupo Aguapeí na definição original de Souza e Hildred (1980) é uma espessa cobertura siliciclástica depositada sobre o Domínio Tectônico Cachoeirinha que se estende da região de Rio Branco em Mato Grosso, até o extremo ocidental do escudo pré-cambriano da Bolívia, onde recebe a denominação Grupo Sunsás.

No contexto da evolução tectônica do Domínio Cachoeirinha, o magmatismo rapakivi aparentemente não exibe uma associação direta ou reflexa com os eventos orogênicos calimmianos (Orogenia Cachoeirinha - 1590 a $1450 \mathrm{Ma}$ ) ou tonianos (Orogenia Aguapeí/Sunsás - 1050 a 900 Ma).

No início do Neoproterozóico, nota-se expressiva atividade ígnea de natureza básica, caracterizada pelas soleiras e diques máficos alojados nos bancos sedimentares do Grupo Aguapeí e no Batólito Rapakivi Rio Branco. A Suíte Intrusiva Salto do Céu, cujos dados litogeoquímicos reportados por Araújo-Ruiz et al. (2005a) indicam um magmatismo toleítico, caracterizando um evento ígneo tipicamente intraplaca, certamente associado a regimes de esforços extensionais, provavelmente relacionados aos mecanismos de colapso orogênico descritos no cinturão Orogênico Sunsás-Aguapeí (Ruiz, 2005). O perfil esquemático de direção E-W (Figura 2), ilustra o estágio magmático anorogênico, evidenciado pelo Batólito Rapakivi Rio Branco e as relações da Suíte Intrusiva Salto do Céu e o Grupo Aguapeí. 


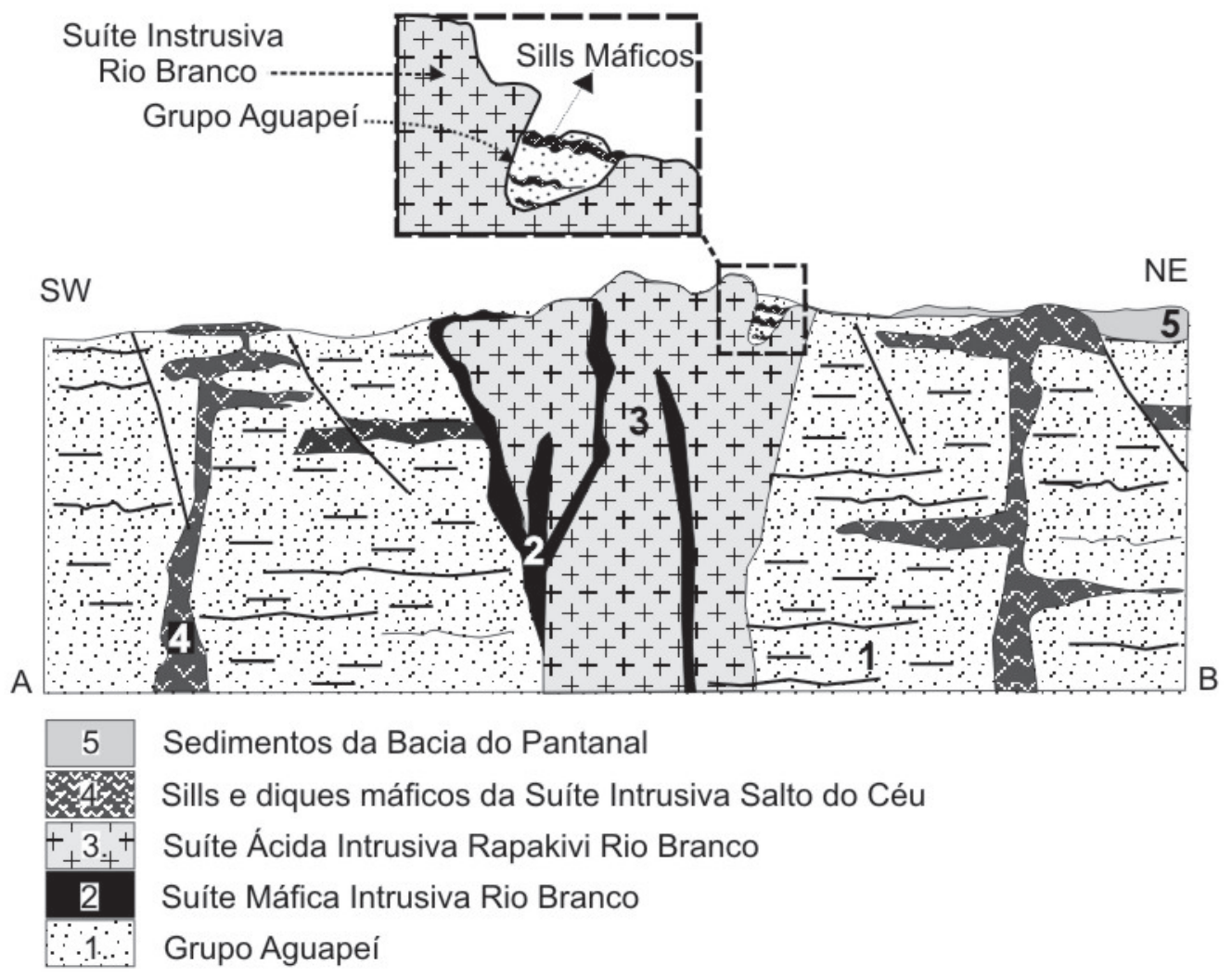

Figura 2. Perfil esquemático (SW-NE) do Batólito Rapakivi Rio Branco e suas encaixantes.

\section{GEOLOGIA LOCAL}

O Grupo Aguapeí é uma espessa cobertura siliciclástica dividida em três formações, compreendendo, da base ao topo, as formações Fortuna, Vale da Promissão e Morro Cristalina. A Formação Fortuna constitui-se por espessos pacotes de conglomerados oligomíticos e arenitos quartzosos, com intercalações, em direção ao topo, de metassiltitos e metargilitos, depositados em um ambiente de mares rasos e correntes de marés. A Formação Vale da Promissão exibe um contato transicional interdigitado com a unidade sotoposta e compreende uma seqüência dominada por metargilitos e metassiltitos e raros metarenitos depositados em um ambiente marinho profundo, sob ação de ondas de tempestades; uma espessa seqüência fluvial encerra a deposição do grupo, com o registro de areias de corrente da Formação Morro Cristalina (Figura 3A).

O Batólito Rapakivi Rio Branco está em contato intrusivo com as rochas encaixantes, representadas pelos metassedimentos da Formação Vale da Promissão do Grupo Aguapeí, que se estende por toda sua borda oeste, enquan- to que nas porções leste são parcialmente recobertos pelos sedimentos quaternários da Formação Pantanal (Figura 4). Na porção noroeste foi possível discriminar as rochas máficas da região de Salto do Céu e Rio Branco, em duas unidades distintas, uma unidade de rochas básicas plutônicas (quartzo-gabros e quartzo-dioritos) pertencentes ao Batólito Rio Branco, com idade de cristalização em torno de 1469 × 31 Ma (Geraldes, 2000) e outra constituída por litotipos hipoabissais, diabásios e microgabros, alojados concordantemente aos estratos do Grupo Aguapeí, com idades entre $878 \pm 10$ Ma e $1015 \pm 17$ Ma definidos por Barros et al. (1982). Para este conjunto de soleiras máficas, exposto nas regiões de Salto do Céu e Rio Branco, Araújo-Ruiz et al. (2005a) sugerem o termo Suíte Intrusiva Salto do Céu.

Na unidade básica plutônica associada ao Batólito Rapakivi Rio Branco, não se verificou o caráter estratiforme diferenciado proposto por Leite et al. (1985), mas uma distribuição descontínua na borda do batólito. Quanto aos aspectos evolutivos propostos por Geraldes et al. (2004) que reforçam o caráter da suíte bimodal e a geração de litotipos híbridos e texturas commingling ocorrendo na interface, 
nota-se em campo a ocorrência de monzogranitos a quartzo monzonitos rapakivi vermelhos com matriz mais escura, tanto no perfil de Salto do Céu em que o autor define o hibridismo, como em várias ocorrências localizadas e de dimensões restritas no interior do batólito, e envolvidas pelas rochas dos leuco-monzogranitos rapakivi vermelho, sendo possível a caracterização em mapa de duas destas ocorrências maiores. Nestas ocorrências não foi verificada a presença de rochas máficas e nem de texturas que levassem à interpretação do processo de hibridismo, mas sim de uma fácies inicial de matriz mais rica em minerais máficos da fácies principal do batólito.

A Suíte Básica Intrusiva Rio Branco situada principalmente na borda oeste da intrusão, é caracterizada petrograficamente por litotipos mesocráticos, de cor cinza a negra, equigranulares de granulação fina às vezes porfirítica, estrutura maciça e constituída por microgabros a diabásios. São rochas constituídas principalmente por plagioclásio, piroxênio (augita e secundariamente pigeonita) e anfibólio alterando-se para clorita, raros quartzos que ocorrem em pequenos grãos intersticiais e como acessórios opacos e a apatita, além de produtos de alteração epidoto e calcita.

A Suíte Ácida Intrusiva Rio Branco ocorre em uma faixa de direção norte-sul, com aproximadamente 75 km de comprimento e $30 \mathrm{~km}$ de largura. Abrange uma área aflorante de cerca de $1.500 \mathrm{~km}^{2}$, ocupando 95\% da área do batólito, destacando afloramentos na forma de blocos e matacões (Figura 3B). O batólito compreende uma fácies básica (indivisa) e 3 fácies ácidas/intermediárias representadas principalmente pelos leuco-monzogranito vermelho rapakivi (Figura 3C) ao lado de quantidades menores de monzogranitos a quartzo monzonitos vermelhos escuros rapakivi (Figura 3D), raros quartzo monzodioritos que ocorrem na forma de enclaves e as fácies tardias de monzogranitos equi-inequigranulares a pegmatóides. Estas fácies são freqüentemente porfiríticas com raros a abundantes fenocristais manteados, constituindo texturas rapakivi e raramente anti-rapakivi. A evolução magmática do batólito é representado concomitantemente por uma fase inicial, definida inicialmente pelas intrusões de rochas básicas laterais ao batólito e localizadamente por enxames de enclaves de diques sin-intrusivos básicos no interior do maciço (Figura 3E), acompanhado por rochas de composição intermediária, preservada por micro-enclaves de quartzo monzodioritos e pelas fácies de monzogranitos a quartzo monzonitos vermelho escuro rapakivi. A fase principal é caracterizada pelas grandes massas de leucomonzogranitos rapakivi que constituem a parte central do batólito e a fase final é constituída pelas fácies equigranulares e aplíticas que cortam todas as anteriores, às vezes, com feições pegmatíticas. Todo o conjunto plutônico não exibe evidências de deformação dúctil e metamorfismo, sendo apenas recortado por falhas normais de direção NNW e
NEE que afetam também suas encaixantes (Figura 4).

Os monzogranitos equi-inequigranulares a pegmatóides são caracterizados por veios centimétricos que ocorrem ao longo do maciço e constituídos por aplitos e pegmatitos. Caracterizam-se por rochas hololeucocráticas a leucocráticas, compostas por microclínio pertítico, oligoclásio, quartzo e rara biotita ao lado de zircão, apatita, titanita, allanita e opacos.

A fácies leuco-monzogranito vermelho rapakivi apresenta composição monzogranítica com textura rapakivi, isotrópicos, porfiríticos de cor vermelha a rosa, leucocráticos, com matriz de granulação fina a média, mostrando por vezes uma tendência para porções grossas, mas não sendo individualizada a sua abrangência. As feições porfiríticas, com textura predominante rapakivi, em matriz de granulação fina a média são dominantes (Figura 3C). Os fenocristais são freqüentemente arredondados a subeuédricos, de até $4 \mathrm{~cm}$ de comprimento, mas dominando o tamanho médio de 1 a $2 \mathrm{~cm}$.

O microclínio é comumente pertítico com formas subedrais de hábito tabular, porém dominando as formas com bordas corroídas e ovaladas apresentando texturas rapakivi. Estas texturas podem ser contínuas ou descontínuas envolvendo os fenocristais. Parte dos cristais de quartzo apresenta-se freqüentemente com feições de corrosão das suas bordas gerando arredondamentos dos grãos. A outra parte é anédrica. O plagioclásio ocorre como grãos subeuédricos, parcialmente alterados, moderadamente a fortemente zonado e, freqüentemente como coroas nos feldspatos alcalinos. O mineral máfico principal é a biotita sob a forma de finas placas anedrais a subedrais, ou apresentando-se aglutinadas, alterando-se comumente para clorita. Os minerais acessórios são a titanita, o opaco, o zircão e a apatita. Os minerais de alteração são constituídos principalmente por sericita e epidoto.

Os monzogranitos a quartzo monzonitos vermelhos escuros rapakivi são formados por rochas leucocráticas de coloração vermelha escura, caracterizadas por apresentarem texturas rapakivi, sejam elas bem definidas, homogêneas em todo o contorno ou irregulares e descontínuas. Às vezes, os fenocristais caracterizam-se por um zoneamento, dado pela formação de feldspato com texturas rapakivi e nova geração de feldspato nas partes externas. Os fenocristais de feldspato potássico são subedrais, com contornos parcialmente ovalados, porém quando apresentam texturas rapakivi exibem basicamente formas ovaladas, tamanhos inferiores a $1 \mathrm{~cm}$ e porcentagens inferiores à fácies principal. Os fenocristais de plagioclásio são subedrais e ocorrem em menores proporções e o quartzo globular é raro, predominando a forma anedral, intersticial e granular em matriz dominantemente de granulação fina. A coloração escura deve-se à presença mais acentuada de biotita em pequenas palhetas dispersas ou 

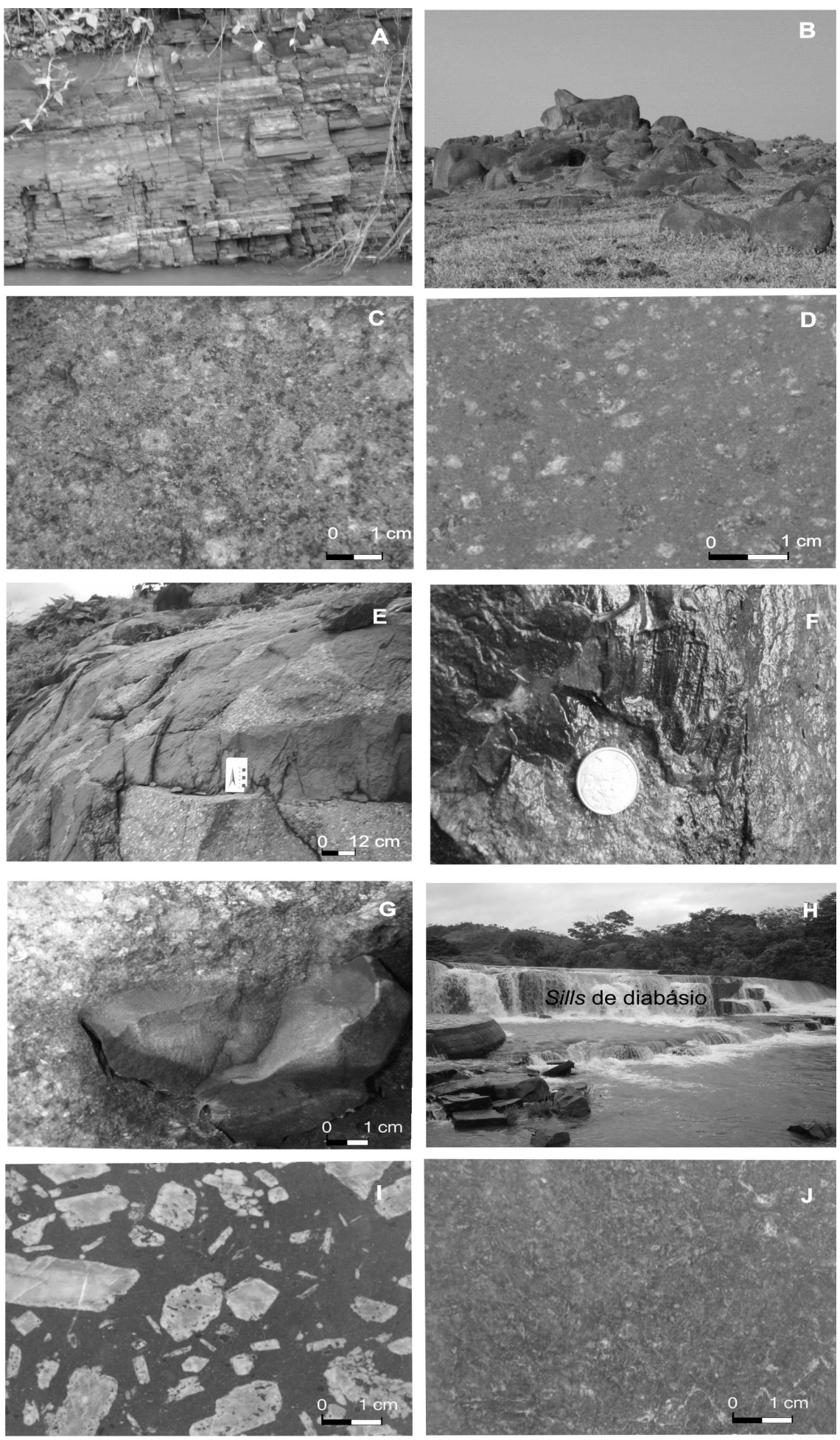

Figura 3. Fotografias de afloramento. A. Metargilito do Grupo Aguapeí. B. Forma de afloramento do Batólito Rio Branco. C. Monzogranito a quartzo monzonito rapakivi escuro. D. Leuco-monzogranito vermelho rapakivi. E. Diques máficos sinintrusivos no leuco-monzogranito. F. Xenólitos de metargilito do Grupo Aguapeí no leuco-monzogranito. G. Xenólito de quartzo monzodiorítico equigranular no leuco-monzogranito. H. Sills de diabásios da Suíte Intrusiva Salto do Céu na cachoeira da cidade de Salto do Céu. I. Quartzo diabásio porfirítico. J. Basalto equigranular. 


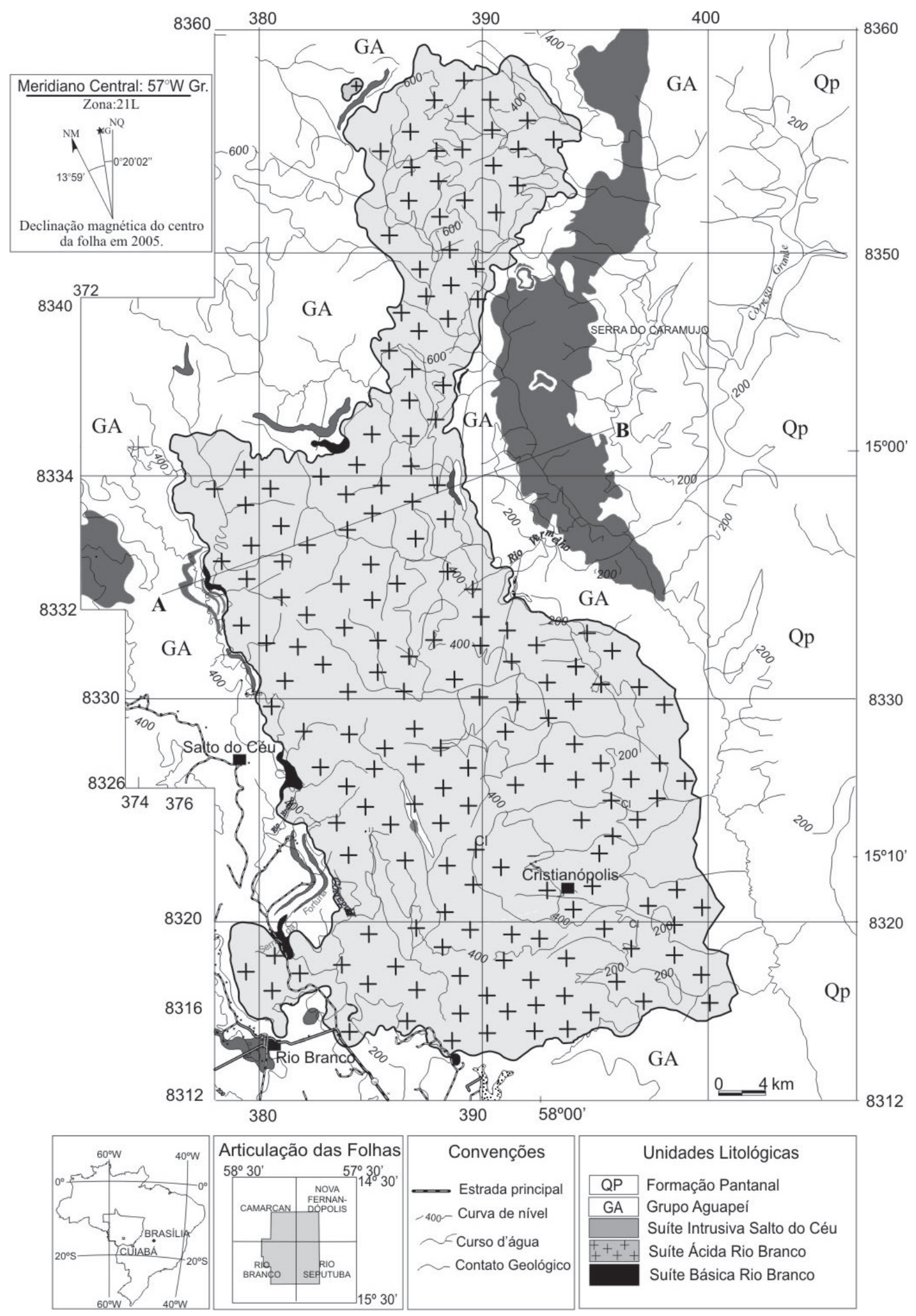

Figura 4. Mapa geológico do Batólito Rapakivi Rio Branco e suas encaixantes. (Extraído de Araújo-Ruiz et al., 2005b). 
aglutinadas (Figura 3D). Na Figura 3F, observa-se xenólito de metargilito do Grupo Aguapeí em paragênese de metamorfismo de contato e na Figura 3G, xenólito microgranular de composição quartzo monzodiorítica.

A Suíte Intrusiva Salto do Céu encontra-se constituída pelas soleiras máficas e representa importante registro magmático de natureza básica, encaixada nos estratos horizontais a levemente inclinados do Grupo Aguapeí. É composta por dezenas de soleiras máficas, com espessura variando entre 1 a $5 \mathrm{~m}$, paralelas ao acamamento dos pelitos e psamitos da formação Vale da Promissão.

Os sills são constituídos por rochas mesocráticas, cinza escuras a negras, equigranulares de granulação fina a média, raramente porfiríticas, maciças que variam texturalmente de microgabros a diabásios. O plagioclásio (labradoritaandesina) ocorre comumente na matriz como cristais euédricos a subeuédricos, tabulares, e menos freqüentemente, como fenocristais de até $5 \mathrm{~cm}$ de comprimento. A matriz é composta por plagioclásio, hornblenda, biotita, feldspato potássico e quartzo. A textura ofítica é comum e os minerais acessórios são representados pelo zircão, titanita, magnetita, ilmenita e pirita. A Figura 3H evidencia afloramento na forma de sills de diabásio na cachoeira da cidade de Salto do Céu, e as Figuras 3I e 3J representam variedades das rochas dos sills, sendo que a primeira apresenta textura porfirítica e a segunda equigranular.

Os Sedimentos da Bacia do Pantanal ocorrem no limite oeste do batólito e são caracterizados pelas coberturas quaternárias da Formação Pantanal.

\section{LITOGEOQUÍMICA}

Os aspectos geoquímicos deste trabalho encontram-se restritos ao estudo das rochas intermediárias e ácidas, enquanto a geoquímica das rochas básicas, com valores de $\mathrm{SiO}_{2}$ no intervalo de $45 \%$ a $55 \%$, encontra-se descrita em Araújo-Ruiz et al. (2005a). As análises químicas (Tabelas 1 e2) foram realizadas no LABOGEO-IGCE/UNESP - Rio Claro, utilizando-se Fluorescência de Raios X para os elementos maiores (concentração em \%), através de pastilha fundida em meio borato e para os elementos traços (concentração em ppm), através de pastilha prensada, e para os elementos de terras raras, ICP-AES, segundo Malagutti et al. (1988). Os trabalhos de cunho geoquímico desta suíte foram descritos inicialmente em Geraldes (2000); Geraldes et al. (2004). Posteriormente, em Araújo-Ruiz et al. (2004, 2005b), são apresentados novos dados geoquímicos, que aliados aos dados químicos deste trabalho, encontram-se integrados na Tabela 1.

As correlações dos elementos maiores podem ser visualizadas nos diagramas de variações binários de Harker (1909) (Figuras 5A a 5H). O conjunto de rochas intermediárias a ácidas apresenta valores entre 55 a $73 \%$ de $\mathrm{SiO}_{2}$. As rochas intermediárias são caracterizadas por quartzo monzonitos com valores entre 55 a $62 \%$ de $\mathrm{SiO}_{2}$. A fase principal é constituída por monzogranitos, com teores entre 68 a $73 \%$ de $\mathrm{SiO}_{2}$, enquanto que a fase mais tardia, constituída por monzogranito equi-inequigranular apresenta também valores elevados de $\mathrm{SiO}_{2}$. Os demais óxidos relacionados na Figura 5 apresentam padrão e correlação normais a todas as rochas de composição granítica.

No diagrama de classificação petrográfica que utiliza os parâmetros multicatiônicos Q versus P, de Debon et al. (1988) (Figura 6A), observa-se que os pontos representativos das rochas estudadas coincidem, predominantemente, com os domínios composicionais correspondentes aos granitos e quartzo monzonitos. O diagrama Q-A-P de Lê Maitre (1989) (Figura 6B) define para o conjunto principal de amostras a composição monzogranítica, com exceção das amostras de quartzo monzonitos.

No diagrama de Peacock (1931) (Figura 6C), considerando também as raras amostras dos monzogranitos a monzonitos vermelho escuro, constitui-se um índice de aproximadamente 52, como um complexo álcali-cálcico.

No diagrama de classificação com relação ao teor em potássio de Taylor (1976) (Figura 6D), parte das amostras da fácies intermediária e raras amostras da fácies principal são identificadas como pertencentes à série cálcio-alcalina de alto potássio, sendo o maior número das amostras da fácies principal pertencentes à série shoshonítica.

Quanto ao diagrama de Maniar e Picolli (1989) (Figura 6E) os litotipos evidenciam caráter peraluminoso a metaluminoso. O diagrama de Debon e Le Fort (1983) (Figura 6F) define para o batólito uma seqüência predominante de rochas peraluminosas a duas micas (campos II) e à biotita (campo III) e rochas metaluminosas à biotita e hornblenda (campo IV).

Quanto aos aspectos tectônicos no diagrama de Batchelor e Bowden (1985) (Figura 7A), as amostras estão dispostas no campo sin-colisional a tardi-orogênico e nos diagramas de Pearce et al. (1984) (Figuras 7B e 7C), verifica-se que as amostras distribuem-se no campo de granitos pós-colisionais a anorogênicos, gerados em ambiente intraplaca.

No variograma para elementos traços normalizados segundo Taylor e McLennan (1985) (Figura 5D), observa-se um padrão bastante simétrico, com empobrecimento em Rb, $\mathrm{Nb}$, Ti e $\mathrm{Sr}$, e enriquecimento em $\mathrm{Ba}$. As razões baixas de $\mathrm{Ba} / \mathrm{Rb}$ evidenciam rochas altamente diferenciadas, geradas a partir de processo de diferenciação magmática.

O comportamento geral dos elementos terras raras das diversas faciologias dos maciços em relação ao padrão adotado para a crosta inferior do condrito de Boynton (1984) (Figura 7E), evidencia padrões com uma disposição subparalela muito regular entre as fácies (Figuras 7F, 7G, $7 \mathrm{H}$ ), apresentando uma forte assimetria, gerados por um enriquecimento em elementos terras raras leves em relação 
Tabela 1. Tabela de geoquímica das rochas da Suíte Intrusiva Ácida Rio Branco.

\begin{tabular}{|c|c|c|c|c|c|c|c|c|c|c|c|c|c|}
\hline Amostras & Aplito & & & & & & Fácies & rincipal & & & & & \\
\hline $\mathrm{SiO}_{2}$ & 70,71 & 71,72 & 71,91 & 71,84 & 70,03 & 71,75 & 72,15 & 71,44 & 72,27 & 72,11 & 72,54 & 72,33 & 70,98 \\
\hline $\mathrm{TiO}_{2}$ & 0,41 & 0,41 & 0,4 & 0,4 & 0,58 & 0,42 & 0,44 & 0,47 & 0,4 & 0,42 & 0,38 & 0,41 & 0,42 \\
\hline $\mathrm{Al}_{2} \mathrm{O}_{3}$ & 12,53 & 12,61 & 13,02 & 12,78 & 14,32 & 12,67 & 12,77 & 12,97 & 12,64 & 13 & 12,57 & 12,53 & 12,67 \\
\hline $\mathrm{Fe}_{2} \mathrm{O}_{3}$ & 5,28 & 3,85 & 3,72 & 3,85 & 4,75 & 3,87 & 3,8 & 4,07 & 3,55 & 3,85 & 3,12 & 3,63 & 3,81 \\
\hline $\mathrm{MnO}$ & 0,08 & 0,08 & 0,08 & 0,08 & 0,05 & 0,08 & 0,09 & 0,1 & 0,09 & 0,09 & 0,05 & 0,09 & 0,11 \\
\hline $\mathrm{MgO}$ & 0,41 & 0,44 & 0,22 & 0,28 & 0,85 & 0,28 & 0,32 & 0,41 & 0,55 & 0,42 & 0,22 & 0,41 & 0,52 \\
\hline $\mathrm{CaO}$ & 0,68 & 0,8 & 1,06 & 0,75 & 1,58 & 0,94 & 0,96 & 0,86 & 0,6 & 0,84 & 1,01 & 0,82 & 0,75 \\
\hline $\mathrm{Na}_{2} \mathrm{O}$ & 3,2 & 3,38 & 3,48 & 3,8 & 2,58 & 3,07 & 3,15 & 3,31 & 2,91 & 2,79 & 3,41 & 3,27 & 3,25 \\
\hline $\mathrm{K}_{2} \mathrm{O}$ & 5,44 & 5,65 & 5,33 & 5,3 & 4,51 & 5,4 & 5,42 & 5,35 & 5,78 & 5,56 & 5,35 & 5,49 & 5,49 \\
\hline $\mathrm{P}_{2} \mathrm{O}_{5}$ & 0,06 & 0,06 & 0,06 & 0,06 & 0,14 & 0,06 & 0,06 & 0,08 & 0,05 & 0,06 & 0,06 & 0,06 & 0,06 \\
\hline LOI & 1,18 & 1,1 & 0,74 & 0,88 & 0,6 & 1,5 & 0,82 & 0,95 & 1,16 & 0,88 & 1,31 & 0,98 & 0,94 \\
\hline Total & 99,99 & 100 & 100 & 100 & 100,02 & 100,04 & 100 & 100,01 & 100,01 & 100,02 & 100,02 & 100,01 & 98,99 \\
\hline $\mathrm{Cu}$ & 10 & 7 & 7 & 6 & 11 & 1 & 7 & 6 & 12 & 9 & 7 & 8 & 16 \\
\hline $\mathrm{Rb}$ & 156 & 165 & 166 & 140 & 153 & 123 & 160 & 146 & 168 & 155 & 158 & 158 & 155 \\
\hline $\mathrm{Sr}$ & 66 & 67 & 85 & 92 & 111 & 41 & 81 & 94 & 71 & 138 & 67 & 66 & 73 \\
\hline$Y$ & 283 & 75 & 68 & 75 & 59 & 64 & 82 & 86 & 85 & 81 & 71 & 79 & 77 \\
\hline $\mathrm{Zr}$ & 503 & 507 & 465 & 474 & 282 & 390 & 505 & 534 & 510 & 544 & 489 & 499 & 494 \\
\hline $\mathrm{Nb}$ & 28 & 24 & 22 & 21 & 15 & 24 & 27 & 28 & 29 & 29 & 27 & 28 & 28 \\
\hline $\mathrm{Ba}$ & 1388 & 1396 & 1382 & 1439 & 1027 & 1296 & 1455 & 1631 & 1590 & 1487 & 1071 & 1282 & 1320 \\
\hline La & 258 & 100 & 92 & 106 & 115 & 68 & 101 & 112 & 98 & 92 & 92 & 91 & 97 \\
\hline $\mathrm{Ce}$ & 218 & 192 & 204 & 198 & 170 & 152 & 172 & 192 & 161 & 159 & 190 & 176 & 176 \\
\hline $\mathrm{Nd}$ & 45,7 & 63,4 & 56,4 & 37,4 & 62,4 & 144 & 73,1 & 73,4 & 90,9 & 69,2 & 56,4 & 73,2 & 60,7 \\
\hline $\mathrm{Sm}$ & 11,3 & 12 & 8,91 & 12,1 & 27,9 & 14,2 & 14,7 & 18,5 & 12,8 & 15 & 11,7 & 13,7 & 14 \\
\hline $\mathrm{Eu}$ & 2,85 & 1,87 & 1,5 & 2,28 & 1,97 & 4,74 & 2,16 & 2,24 & 2,74 & 1,89 & 1,5 & 2,26 & 1,7 \\
\hline $\mathrm{Cr}$ & 138 & 184 & 169 & 174 & 169 & 251 & 129 & 137 & 142 & 182 & 120 & 149 & 147 \\
\hline $\mathrm{Ni}$ & 7 & 6 & 7 & 7 & 12 & 4 & 6 & 5 & 5 & 7 & 4 & 5 & 6 \\
\hline $\mathrm{Gd}$ & 10,2 & 11,2 & 10,7 & 8,07 & 11,8 & 33,2 & 12,2 & 12,5 & 13,4 & 10,8 & 10,7 & 12,5 & 11,3 \\
\hline Dy & 8,21 & 9,62 & 9,4 & 8,42 & 10,8 & 30,9 & 11,8 & 11,4 & 14,5 & 11,4 & 9,4 & 12,4 & 10,6 \\
\hline $\mathrm{Er}$ & 3,79 & 6,47 & 4,95 & 3,68 & 6,61 & 18,5 & 7,32 & 7,06 & 8,58 & 6,9 & 4,95 & 8,36 & 6,33 \\
\hline $\mathrm{Yb}$ & 2,71 & 6,2 & 3,75 & 3,19 & 5,4 & 12,3 & 6,79 & 6,52 & 7,89 & 6,3 & 3,75 & 7,42 & 4,68 \\
\hline Lu & 0,35 & 0,87 & 0,56 & 0,43 & 0,8 & 1,8 & 0,87 & 0,9 & 1,16 & 0,84 & 0,56 & 1,06 & 0,65 \\
\hline $\mathrm{La}$ & 37,3 & 61,1 & 57,5 & 28 & 65,6 & 147 & 74,7 & 70,3 & 92,1 & 71 & 57,5 & 78,1 & 66,8 \\
\hline
\end{tabular}

Tabela 2. Tabela de geoquímica das rochas da Suíte Intrusiva Ácida Rio Branco.

\begin{tabular}{|c|c|c|c|c|c|c|c|c|c|c|c|c|c|c|}
\hline \multirow{2}{*}{$\frac{\text { Amostras }}{\mathrm{SiO}_{2}}$} & \multicolumn{11}{|c|}{ Fácies principal } & \multicolumn{3}{|c|}{ Fácies intermediária } \\
\hline & 72,04 & 72,06 & 71,92 & 71,34 & 72,09 & 71,31 & 71,95 & 71,51 & 72,62 & 71,63 & 72,53 & 55,34 & 61,5 & 61,89 \\
\hline $\mathrm{TiO}_{2}$ & 0,4 & 0,43 & 0,46 & 0,56 & 0,41 & 0,43 & 0,43 & 0,41 & 0,45 & 0,46 & 0,49 & 2,7 & 1,58 & 1,63 \\
\hline $\mathrm{Al}_{2} \mathrm{O}_{3}$ & 12,88 & 12,69 & 12,46 & 12,36 & 12,9 & 12,81 & 12,72 & 13,07 & 12,46 & 12,72 & 12,24 & 13,48 & 13,37 & 13,03 \\
\hline $\mathrm{Fe}_{2} \mathrm{O}_{3}$ & 3,68 & 3,75 & 4,14 & 4,39 & 3,91 & 4,3 & 3,86 & 3,84 & 4,03 & 4,05 & 3,95 & 12,08 & 9,23 & 9,44 \\
\hline $\mathrm{MnO}$ & 0,08 & 0,09 & 0,09 & 0,11 & 0,07 & 0,11 & 0,09 & 0,08 & 0,1 & 0,11 & 0,11 & 0,17 & 0,13 & 0,15 \\
\hline $\mathrm{MgO}$ & 0,28 & 0,43 & 0,57 & 0,57 & 0,47 & 0,6 & 0,19 & 0,6 & 0,45 & 0,45 & 0,36 & 3,15 & 1,95 & 1,89 \\
\hline $\mathrm{CaO}$ & 0,78 & 0,68 & 0,57 & 1,25 & 0,25 & 0,66 & 1,09 & 0,63 & 0,85 & 0,87 & 1,05 & 6,04 & 3,1 & 3,22 \\
\hline $\mathrm{Na}_{2} \mathrm{O}$ & 3,5 & 3,48 & 3,21 & 3,3 & 2,53 & 3,22 & 3,3 & 3,19 & 2,7 & 3,15 & 3,12 & 3,35 & 3,84 & 3,5 \\
\hline $\mathrm{K}_{2} \mathrm{O}$ & 5,54 & 5,33 & 5,3 & 5,23 & 6,16 & 5,45 & 5,23 & 5,28 & 5,49 & 5,33 & 5,28 & 2,64 & 4 & 3,98 \\
\hline $\mathrm{P}_{2} \mathrm{O}_{5}$ & 0,07 & 0,06 & 0,07 & 0,09 & 0,06 & 0,06 & 0,07 & 0,06 & 0,07 & 0,07 & 0,08 & 0,61 & 0,33 & 0,35 \\
\hline LOI & 0,81 & 1,01 & 1,22 & 0,82 & 1,18 & 1,04 & 1,07 & 1,33 & 0,76 & 1,17 & 0,81 & 0,63 & 1 & 0,94 \\
\hline Total & 100,07 & 100 & 100,02 & 100,01 & 100,02 & 100,01 & 100,01 & 100 & 99,99 & 100,01 & 100,02 & 100,2 & 100 & 100 \\
\hline $\mathrm{Cu}$ & 7 & 8 & 13 & 3 & 8 & 6 & 9 & 16 & 8 & 6 & 3 & 36 & 25 & 23 \\
\hline $\mathrm{Rb}$ & 169 & 153 & 132 & 152 & 151 & 154 & 151 & 144 & 154 & 157 & 161 & 68 & 112 & 104 \\
\hline $\mathrm{Sr}$ & 80 & 59 & 56 & 74 & 140 & 77 & 78 & 65 & 140 & 64 & 85 & 252 & 176 & 193 \\
\hline$Y$ & 70 & 77 & 88 & 73 & 79 & 74 & 87 & 100 & 80 & 80 & 81 & 56 & 70 & 68 \\
\hline $\mathrm{Zr}$ & 477 & 503 & 484 & 471 & 490 & 485 & 519 & 500 & 533 & 496 & 487 & 344 & 430 & 445 \\
\hline $\mathrm{Nb}$ & 30 & 28 & 26 & 26 & 26 & 26 & 28 & 29 & 29 & 28 & 26 & 19 & 23 & 23 \\
\hline $\mathrm{Ba}$ & 1577 & 1375 & 1311 & 1423 & 1983 & 1507 & 1338 & 1250 & 1489 & 1333 & 1403 & 969 & 1268 & 1164 \\
\hline La & 98 & 92 & 79 & 98 & 101 & 85 & 102 & 116 & 83 & 103 & 93 & 80 & 90 & 93 \\
\hline $\mathrm{Ce}$ & 202 & 159 & 165 & 163 & 200 & 159 & 178 & 164 & 155 & 170 & 172 & 131 & 159 & 138 \\
\hline $\mathrm{Nd}$ & 65,2 & 68,2 & 70,9 & 70,4 & 63,6 & 70,5 & 64,4 & 38,4 & 63,6 & 56,4 & 54,1 & 63,4 & 73,2 & 77 \\
\hline $\mathrm{Sm}$ & 13,7 & 14 & 13,7 & 15,1 & 13,3 & 11,3 & 13,4 & 9,08 & 13,3 & 12 & 11,1 & 11,9 & 14,6 & 15,7 \\
\hline $\mathrm{Eu}$ & 1,91 & 2,11 & 2,14 & 2,33 & 2,01 & 1,3 & 1,99 & 2,43 & 2,01 & 1,5 & 2,17 & 1,87 & 2,41 & 2,21 \\
\hline $\mathrm{Ni}$ & 6 & 6 & 4 & 4 & 6 & 5 & 6 & 5 & 8 & 7 & 6 & 27 & 20 & 20 \\
\hline $\mathrm{Cr}$ & 177 & 131 & 146 & 143 & 197 & 181 & 159 & 137 & 193 & 165 & 158 & 116 & 151 & 118 \\
\hline $\mathrm{Gd}$ & 11,7 & 10,9 & 11,8 & 12,6 & 10,7 & 5,7 & 10 & 8,22 & 10,7 & 10,7 & 11,2 & 11,2 & 13,5 & 13,5 \\
\hline Dy & 10,4 & 10,9 & 11,5 & 12,7 & 9,74 & 12 & 10,3 & 6,62 & 9,74 & 9,4 & 9,57 & 9,62 & 12,1 & 12,6 \\
\hline $\mathrm{Er}$ & 7 & 7,53 & 7,38 & 7,57 & 5,93 & 1,5 & 6,69 & 3,77 & 5,93 & 4,95 & 5,88 & 6,47 & 7,28 & 8,44 \\
\hline $\mathrm{Yb}$ & 5,97 & 6,47 & 6,04 & 6,77 & 5,2 & 1,07 & 5,95 & 2,84 & 5,2 & 3,75 & 5,28 & 6,2 & 7,44 & 6,76 \\
\hline Lu & 0,94 & 0,88 & 0,91 & 1,02 & 0,66 & 0,16 & 0,88 & 0,34 & 0,66 & 0,56 & 0,75 & 0,87 & 1,07 & 0,91 \\
\hline
\end{tabular}


Geologia e Geoquímica do Batólito Rapakivi Rio Branco,... Ge Cérie Científica
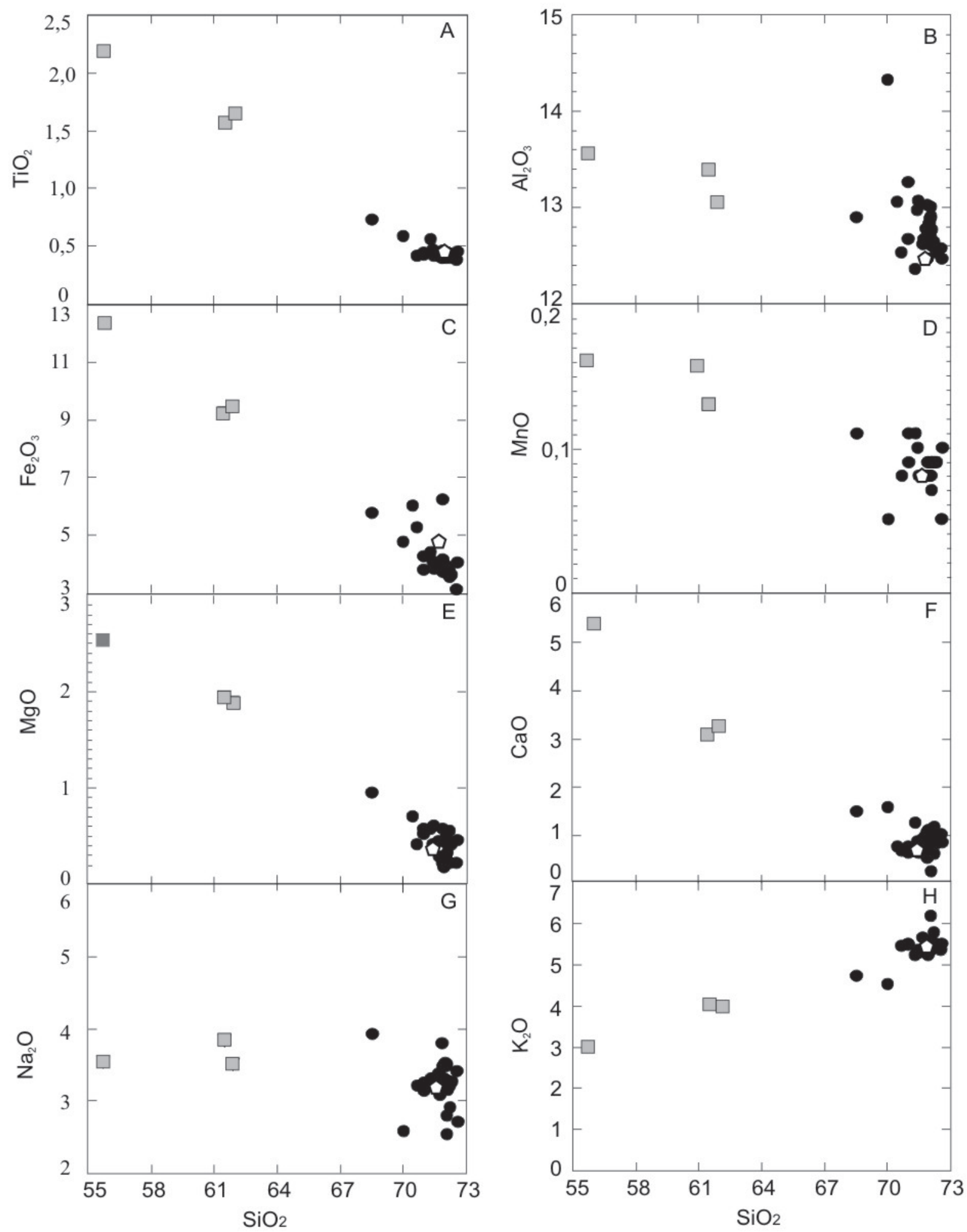

Figura 5. Diagramas de variação de elementos maiores (Harker, 1909). $\Delta=$ monzogranito equi a inequigranular. $=$ Leuco-monzogranito vermelho rapakivi. $\square=$ Monzogranito a quartzo monzonito rapakivi escuro. 

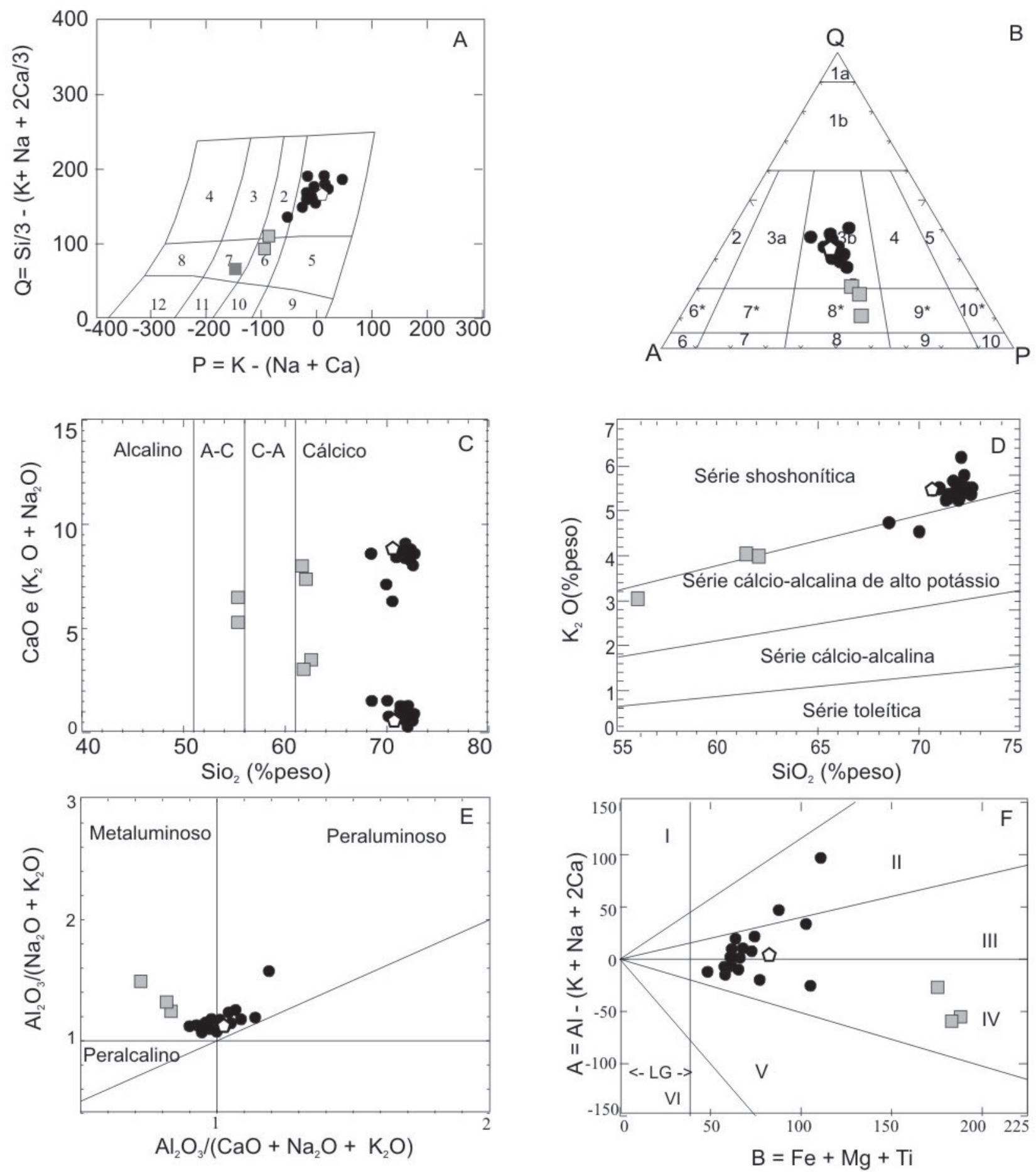

Figura 6. Diagramas de classificação geoquímica. A. Debon e Le Fort (1983): 1 - Sienogranito, 2 - Monzogranito, 6 - Quartzo-monzonito, 7 - Quartzo-monzodiorito. B. Le Maitre (1989): 3b - Monzogranito, 8* - Quartzo-monzonito. C. Peacock (1931). D. Taylor (1976). E. Maniar e Picolli (1989). F. Debon e Le Fort (1983): II e III - Granito Peraluminoso, IV - Granito Metaluminoso. $\Delta=$ monzogranito equi a inequigranular. $\mathbf{O}=$ Leuco-monzogranito vermelho rapakivi. $\square=$ Monzogranito a quartzo monzonito rapakivi escuro. 

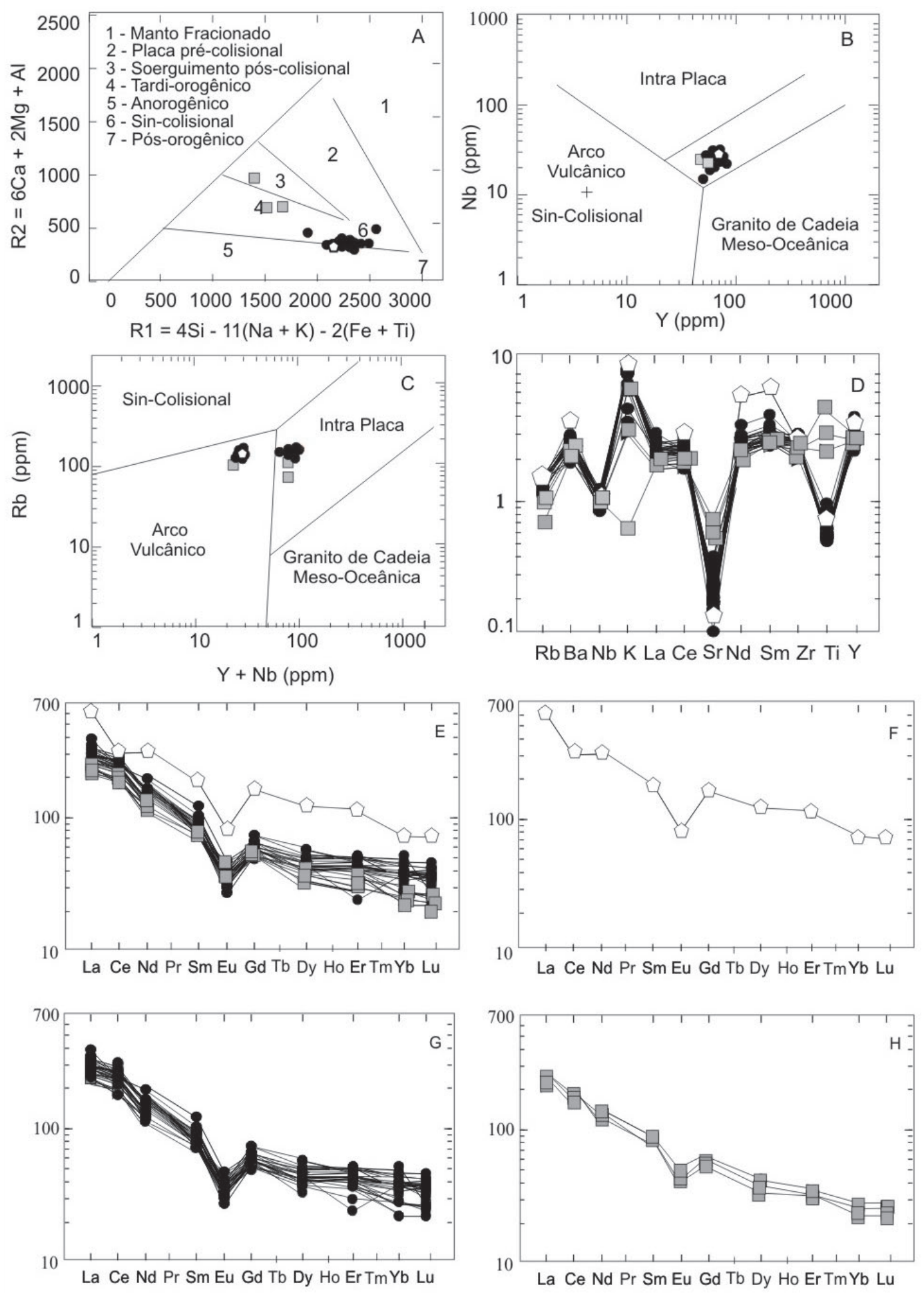

Figura 7. Diagramas de classificação tectônica. A. Batchelor e Bowden (1985). B e C. Pearce et al. (1984). D. Diagramas de elementos traços normalizados segundo Taylor e McLennan (1985). E, F e G. Elementos terras raras normalizados segundo o condrito de Boynton (1984). $\square=$ Leuco-monzogranito equi a inequigranular. $0=$ Leuco-monzogranito vermelho rapakivi. $\square=$ Monzogranito a quartzo monzonito rapakivi escuro. 
ao empobrecimento em elementos terras raras pesadas, e anomalia negativa em Eu. Observa-se o enriquecimento simétrico e contínuo de elementos terras raras e incremento de anomalias negativas de Eu à medida que a fácies tornase mais diferenciada.

Os valores dos elementos de terras raras das rochas (Figura 7E), apresentam um padrão de distribuição total enriquecido em $[\mathrm{La} / \mathrm{Yb}=9,4]_{\mathrm{N}}$ e fortes anomalias negativas de $\mathrm{Eu}$, com $\left[\mathrm{Eu} / \mathrm{Eu}^{*}=0,55\right]_{\mathrm{N}}$ e um padrão com alta assimetria definida pelo valor de Ce/Sm = 3,4 em relação ao valor de $\mathrm{Gd} / \mathrm{Yb}=1,9$, demonstrando padrões assimétricos e paralelos representando, portanto, amostras cogenéticas, mas distintas, pelo grau de diferenciação.

A fácies tardia dos monzogranitos equi-inequigranulares (Figura 7E) é caracterizada por elevados valores de elementos terras raras leves apresentando $[\mathrm{La} / \mathrm{Yb}=9,3]_{\mathrm{N}}$, forte anomalia negativa de $\mathrm{Eu}$, e $\left[\mathrm{Eu} / \mathrm{Eu}^{*}=0,8\right]$, forte assimetria, devido à alta inclinação de $\mathrm{Ce} / \mathrm{Sm}=2,0$ em relação a $\mathrm{Gd} / \mathrm{Yb}=3,0$.

A distribuição de elementos terras raras da fácies principal de composição leuco-monzogranítica rapakivi (Figura 7G), apresenta um padrão de elementos terras raras leves com $[\mathrm{La} / \mathrm{Yb}=9,8]_{\mathrm{N}}$ e fortes anomalias negativas de $\mathrm{Eu}$, com $\left[\mathrm{Eu} / \mathrm{Eu}^{*}=0,54\right]$, mas apresentando valores inferiores de elementos terras raras leves e pesadas em relação à fácies anterior. A assimetria é definida pela forte inclinação de $\mathrm{Ce} / \mathrm{Sm}$ = 3,4 em relação a $\mathrm{Gd} / \mathrm{Yb}=1,84$.

A fase intermediária (Figura $7 \mathrm{H}$ ), composta por monzogranitos e quartzo-monzonitos, apresenta um padrão de distribuição com $[\mathrm{La} / \mathrm{Yb}=6,7]_{\mathrm{N}}$, fracas anomalias negativas de $\mathrm{Eu}$, com [Eu/Eu* $=0,5]$ e padrão assimétrico com inclinação do braço Ce/Sm = 4,0 em relação a $\mathrm{Gd} / \mathrm{Yb}=1,5$, porém caracterizando uma maior redução dos valores de elementos de terras raras leves e pesadas.

\section{CONCLUSÕES}

A partir do mapeamento em 1:100.000 das rochas que constituem o Batólito Rapakivi Rio Branco foi possível definir uma redução significativa de (25\%) da sua área de ocorrência em relação aos mapas geológicos anteriores, com exposição da ordem de $1.500 \mathrm{~km}^{2}$, bem como alteração na sua forma, além de caracterizá-lo como um evento magmático intrusivo nas formações Morro Cristalino e Vale da Promissão do Grupo Aguapeí.

O batólito é constituído por duas suítes plutônicas principais, a primeira, formada pela suíte básica de distribuição descontínua e localizada nas bordas da intrusão e a segunda, pela suíte ácida/intermediária, composta por três fácies petrográficas: monzogranitos equi-inequigranulares a pegmatóides, leuco-monzogranito vermelho rapakivi e monzogranitos a quartzo-monzonitos vermelhos escuros rapakivi.
As relações de campo mostraram que as extensas exposições da associação gabróica representam dois eventos magmáticos independentes: as rochas básicas plutônicas (gabros a quartzo-gabros e dioritos a quartzo-dioritos) pertencentes à borda da Suíte Intrusiva Rio Branco e os litotipos hipoabissais, diabásios e microgabros, agrupados sob a designação Suíte Intrusiva Salto do Céu e alojados concordantemente aos estratos do Grupo Aguapeí.

Com relação à gênese do magmatismo básico e ácido Rio Branco, defende-se o aspecto bimodal, mas apresentando a unidade máfica um comportamento descontínuo e lateral à unidade ácida dominante e não sendo reconhecidos extensos processos de hibridismo das unidades básicas e ácidas a não ser em áreas localizadas e restritas.

Quanto à evolução magmática do Batólito Rapavi Rio Branco sugere-se a sua formação a partir de dois magmas, um de natureza básica gerado por derivação mantélica e outro, de composição ácido/intermediário, formado por processos de fusão de rochas da crosta inferior e através de processo de diferenciação magmática, geraram-se as fácies de composições distintas e cogenéticas, observadas pelo paralelismo dos padrões de distribuição de ETR, enriquecimento em ETRL, empobrecimento de ETRP, anomalias negativas de Eu indicando um fracionamento de Eu, e um crescimento simétrico dos valores de elementos terras raras para as rochas mais diferenciadas e evoluídas.

Os dados geológicos e geoquímicos da Suíte Rapakivi Rio Branco apontam para a geração de um magmatismo de transição entre os tipos I e A, pós-orogênico a anorogênico, representando intrusões tardias no ciclo magmático, relacionados ao final do evento colisional, alcançando níveis mais estáveis de consolidação e estabilização tectônica do SW do Craton Amazônico.

\section{AGRADECIMENTOS}

Ao auxílio financeiro da FAPESP (proc. 2004/00653-5).

\section{REFERÊNCIAS BLIBLIOGRAFICAS}

ARAÚJO-RUIZ, L. M. B.; GODOY, A. M.; SOUZA, M. Z. A.; RUIZ, A. S.; GERALDES, M. C.; MATOS, J. B. Caracterização petrográfica e litogeoquímica preliminar da Suíte Intrusiva Rio Branco na região SW de Mato Grosso. In: CONGRESSOBRASILEIRODE GEOLOGIA, 42., 2004,Araxá. Anais... Araxá: SBG, 2004. (CD-ROM).

ARAÚJO-RUIZ, L. M. B. de; RUIZ, A. S.; GODOY, A. M.; SOUSA, M. Z de A. Soleiras máficas tonianas (Suíte Intrusiva Salto do Céu) no SW do Cráton Amazônico: regime extensional relacionado à Orogenia Sunsás? In: SIMPÓSIO DO CENTRO OESTE, 9., 2005a, Goiânia. Anais ... Goiânia: 
SBG, 2005a. (CD-ROM).

ARAÚJO-RUIZ, L. M. B. de; GODOY, A. M.; RUIZ, A. S.; SOUSA, M. Z. A. de; MONTANO, L. F. M. de. Caracterização geológica e geoquímica do Batólito Rapakivi Rio Branco, SW do Cráton Amazônico - MT. In: CONGRESSO BRASILEIRO DE GEOQUÍMICA, 10. / SIMPÓSIO DE GEOQUÍMICA DOS PAÍSES DO MERCOSUL, 2., 2005b, Porto de Galinhas, PE. Anais... Porto de Galinhas: SBG, 2005b.(CD-ROM).

BARROS, A. M.; SILVA, R. H. da; CARDOSO, O. R. F. A.; FREIRE, F. A.; SOUZA Jr., J. J. da; RIVETTI, M.; LUZ, D. S. da; PALMEIRA, R. C.; TASSINARI, C. C. G. Geologia. In: MINISTÉRIO DAS MINAS E ENERGIA. Projeto Radambrasil, Folha SD.21. Cuiabá. Rio de Janeiro. p. 25-192, 1982. (Levantamentos de Recursos Naturais, 26).

BATCHELOR, R. A.; BOWDEN, P. Petrogenetic interpretation of granitc rock series using multicationic parameters. Chemical Geology, v. 48. n. 1-4, p. 43-55, 1985.

BOYNTON, W. V. Cosmochemistry of the rare-earth elements: meteorite studies. In: HENDERSON, P. (Ed.). Rare-earth elements geochemistry. Amsterdam: Elsevier, 1984. p. 63-114.

DEBON, F.; LE FORT, P. A chemical-mineralogical classification of common plutonic rocks and associations. Transactions of the Royal Society of Edinburgh Earth Sciences, v. 73, p. 135-149, 1983.

DEBON, F.; LE FORT, P.; SABATÉ, P. Uma classificação químico- mineralógica das rochas plutônicas comuns e suas associações, método e aplicações. Revista Brasileira de Geociências, v. 18, n. 2, p. 122-133, 1988.

GERALDES, M. C. Geocronologia e geoquímica do plutonismo mesoproterozóico do SW do Estado de Mato Grosso (SW do Cráton Amazônico). 2000. 193 f. Tese (Doutorado) - Instituto de Geociências, Universidade de São Paulo, São Paulo, 2000.

GERALDES, M. C.; VAN SCHMUS, W. R.; CONDIE, K. C.; BELL, S.; TEIXEIRA, W. ; BABINSKI, M. Proterozoic geologic evolution of the SW part of the Amazonian Craton in Mato Grosso state, Brazil. Precambrian Research. v. 111, p. 91-128, 2001.

GERALDES, M. C.; BETTENCOURT J. S.; TEXEIRA, W.; MATOS J. B. Geochemistry and isotopic constraints on the origin of the mesoproterozoic Rio Branco 'anorogenic' plutonic suíte, SW of Amazônia craton, Brazil: high heat flow and crustal extension behind the Santa Helena arc?. Journal of South American Earth Sciences. v. 17, p. 195-208, 2004.

HARKER, A. The natural history of igneous rocks. London: Methuen, 1909. 384 p.

LE MAITRE, R. W. A. Classification of igneous rocks and glossary of terms: recommendations of the international union of geological-sciences subcommission on the systematics of igneous rocks. Oxford: Blackwell, 1989. 193 p.

LEITE, J. A. D.; SAES, G.; WESKA, R. K. A suíte Rio Branco e o Grupo Aguapeí nas serra de Rio Branco e Roncador In: SIMPÓSIO DE GEOLOGIA DO CENTRO OESTE, 1., 1985, Goiânia. Anais...Goiânia: SBG, 1985. p. 247-255. v. 1.

MALAGUTTI, M. I. A.; BAHIA FILHO, O.; MORENO, M. M. T.; NARDY, A. J. R. Determinação de elementos terras raras e ítrio em rochas silicáticas por ICP-AES com separação em resina trocadora de íons. Geochimica Brasiliensis, São Paulo, v. 12 n.1-2, p. 75-80, 1998.

MANIAR ,P. D.; PICCOLI, P. M. Tectonic discrimination of granitoids. Geological Society of America Bulletin. v. 101, p. 635-643, 1989.

OLIVA, L. A. Ocorrências minerais na Folha Cuiabá (SD. 21). Goiânia: DNPM, 1979. 18 p. (Relatório de Viagem).

PEACOCK, M. A. Classification of igneous rocks series. Journal of Geology. v. 39, n. 1-4, p. 54-67, 1931.

PEARCE, J. A.; HARRIS, N. B. W.; TINDLE, A. G. Trace element discrimination diagrams for the tectonic interpretation of granitic rocks. Journal of Petrology. v. 25, n. 4, p. 956-983, 1984.

RUIZ, A.S. Contribuição a geologia do Distrito de Cachoeirinha, MT. 1992. 118 f. Dissertação (Mestrado) Instituto de Geociências, Universidade de São Paulo, São Paulo, 1992.

RUIZ, A. S. Evolução geológica do sudoeste do Cráton Amazônica região limítrofe Brasil-Bolívia - Mato Grosso. 2005. 260 f. Tese (Doutorado) - Instituto de Geociências e Ciências Exatas, Universidade Estadual Paulista, Rio Claro, 2005.

RUIZ, A. S.; MATOS, J. B.; SIMÕES, L. S. A.; ARAÚJORUIZ, L. M. B. A.; SOUSA, M. Z. A.; GODOY, A. M.; COS- 
TA, P. C. C.; FERNANDES, C. J.; ALMEIDA, H. L. Arcabouço litoestratigráfico e tectônico do Cráton Amazônico no SW de Mato Grosso: revisão e atualização. Cuiabá: Ed. UFMT, 2005. (Coletânea Geológica de Mato Grosso, 1).

SAES, G. S.; FRAGOSO CÉSAR, A. R. S. Acresção de terrenos mesoproterózoicos no SW da Amazônia. In: CONGRESSO BRASILEIRO DE GEOLOGIA, 39., 1996, Salvador. Boletim... Salvador: SBG, 1996. p. 348. v. 1.

SAES, G. S. Evolução tectônica e paleogeográfica do Aulacógeno Aguapeí (1.2 - 1.0 Ga) e dos terrenos do seu embasamento na porção sul do Cráton Amazônico. 1999. 135 f. Tese (Doutorado) - Instituto de Geociências, Universidade de São Paulo, São Paulo, 1999.

SANTOS, J. O. S., MCNAUGHTON, N. J., HARTMANN, L. A., FLETCHER, I. R., SALINAS, R. M. The age of deposition of the Aguapeí Group, Western Amazon Craton, based on $\mathrm{U}-\mathrm{Pb}$ study of diagenetic xenotime and detrital zircon. In: CONGRESO LATINO-AMERICANO DE GEOLOGIA, 12., 2005, Quito, Ecuador. (CD-ROM).

SOUZA, E. P.; HILDRED, P. R. Contribuição ao estudo da geologia do Grupo Aguapeí, oeste de Mato Grosso. In: CONGRESSO BRASILEIRO DE GEOLOGIA, 31., 1980, Camboriu. Anais...Camboriu: SBG, 1980. p. 813-825. v. 2,

TASSINARI, C. C. G.; MACAMBIRA, M. J. B. Geochronological provinces of the Amazonian Craton. Episodes., v. 22, n. 3, p. 174-182, 1999.

TAYLOR, W. P. Intrusion and differentiation of granitic magma at high level in the crust: the Puscao Pluton. Lima Province, Peru. Journal of Petrolog, v. 17, n. 2, p. 82-133, 1976.

TAYLOR, S. R.; McLENNAN, S. M. The continental crust: its composition and evolution. Oxford: Blackwell, 1985. 